\title{
The Influence of Cooperatif Learning Model and Critical Thinking on Essay Writing Skills (Experiment Study)
}

\author{
Febriyantina Istiara ${ }^{1} \&$ Ninuk Lustyantie ${ }^{2, *}$ \\ ${ }^{1}$ STKIP PGRI Bandar Lampung, Indonesia \\ ${ }^{2}$ Universitas Negeri Jakarta, Indonesia \\ *Correspondence: Universitas Negeri Jakarta, Indonesia. E-mail: ninuk.lustyantie@unj.ac.id
}

Received: June 6, 2017

Accepted: June 15, 2017 Online Published: June 28, 2017

doi:10.5430/wjel.v7n2p22

URL: https://doi.org/10.5430/wjel.v7n2p22

\begin{abstract}
The purpose of this research was to find out whether there is any influence on cooperative learning model and critical thinking on English essay writing skills. The data was collected through (1) multiple choice reading test of critical thinking instrument and (2) essay writing test. The research used treatment by level 2 x 2 design. The technique of analysis data used two ways ANOVA. The research finding shows that: 1) it is significant between English essay writing skill between students that was learned by task-based learning and think talk write learning, it is Fh (bk) = 9.93 and $\mathrm{Ft}(0,05(1,40)=4.08$. So, $\mathrm{Fh}(\mathrm{k})>\mathrm{Ft}$ that is interaction. English essay writing skills have studied using task-based learning was better than think talk write learning in high critical thinking with Qaccount 12,91. English essay writing skills have studied using think talk write learning was better than task-based learning in low critical thinking with Qaccount 14.1.
\end{abstract}

Keywords: critical thinking; cooperative learning; essay writing; task-based learning; think talk write learning

\section{Introduction}

English learning process has to make 4 abilities, such as listening, speaking, reading and writing. One of the abilities that are so difficult for students is writing, especially in essay writing learning. Because it needs all comprehension aspect in writing. The essay has several paragraphs. According to Richards dan Renandya (2003:303), There is no doubt that writing is the most difficult skill for L2 learners to master. The difficulty lies not only in generating and organising ideas but also in translating these ideas into readable text. The skills involved in writing are highly complex. L2 writers have to pay attention to higher level skills of planning and organising as well as lower level skills of spelling, punctuation, word choice, and so on.

From that suggest, it concluded that writing learning has a different main purpose in university with the students in senior high school. It emphasised by Murray (2012:9), Some of the major differences between writing at school and writing at university. The vast bulk of your education at high school consists largely of developing discipline in your approach to study and building up a body of knowledge that will prepare you for the outside world - both the social world and the world of work - and for the studies, you may choose to undertake as an undergraduate student. In contrast, university education exists to build on that foundation with a view to further developing your intellect and powers of analysis, your specialist knowledge of the subject you have chosen to study and your ability to play a role in taking forward that field of study through your own ideas and creativity. This shift of emphasis as you move from high school to university is reflected in the expectations tutors have of your writing

For a student in a college, learning writing leads to the intellectual development and strength analysis in accordance with the field of scientific study. The students' ability has been used for developing ideas and creativity in creating ideas. So students make writing at the level of analysis and produce development of the new idea. At this level, students not only oriented to the product but the process in which happened learning integrated. The condition of the ideal as expected in a course English in STKIP PGR Lampung, Indonesia, as articulated in vision and mission.

While the result of observations and interview show that the students in English program STKIP PGRI Lampung Indonesia still experienced difficulty in learning writing essay. It is not something can be conducted easily without 
any the planning and preparation. Fellag (2004:53) stated that essay such as short essay can be understood as a composition of several paragraphs, two until ten paragraph about one topic. It is the same view, Blanchard and Root (2004:60) stated that an essay is a group of the paragraph that has one topic.

Essay learning is a set of long paragraphs. An essay is a short collection of paragraphs that presents facts, opinions, and ideas about a topic. According to Folse, Vokoun and Solomon (2014:5) that an essay has three basic parts: introduction, body paragraph, and conclusion. The introduction is the first paragraph, the conclusion is the last paragraph, and the body consists of the paragraph or paragraphs in between. The most basic and versatile format for an essay consists of five paragraphs. In a typical five-paragraph essay, paragraph one introduces the topic, paragraphs two through four develop the topic by giving details, and paragraph five concludes the essay.

Those are been a difficult way to the student in arranging the essay. The students have to think some components of writing construction. Brown and Barley (2003:244), designed an analytic scoring scale that specified five major categories and a description of five different levels in each category. The five categories are; (1) organisation (introduction, body and conclusion), (2) logical development of ideas, (3) grammar, (4) punctuation, spelling, and mechanics, and (5) styles and quality of expression. Thus, if it refers to the step in writing process, it will be easy. According to Scarry and Scarry (2011:4) stated that the writing process has three steps, 1) prewriting stages, 2) writing and revising, 3) proofreading. These steps help the students to make a good essay.

Observation data found that the student in English Department STKIP PGRI Bandar Lampung Indonesia has the low score of essay writing learning in the past three years. It conducted in 2014, 2015, and 2016. In 2014, there is about $57 \%$ of students' essay writing score in grades D, in 2015 is about $66 \%$ of students' essay writing score in grades D and in 2016 is about $62 \%$ of students' essay writing score in grades D. So, the observation data of essay writing score is great attention for the lecture in the past three years. The causes indicator of problems arises; 1) writing skill learning is not only pertaining to write a language in literary or symbol but it is a process of thought and requires cognitive and affective ability. Moreover, the process of essay writing at the college level had entered the interpretation and analysis or development of the analysis. So the students need the critical thinking in writing. When an author does not turn thinking process, of course, he could not engage in the writing.

The ability of critical thinking is very useful and helps in the writing and speaking learning. As revealed by Browne, et.al. (2007: 2) namely (1) react critically to an essay or to evidence presented in a textbook, a periodical, or on a Web site, (2) judge the quality of a lecture or speech, (3) form an argument, (4) write an essay based on a reading assignment, and (5) participate in class. According to Dunn, Halonen and Smith (2008:163 \& 167) that Critical thinking is not one strategy, but many strategies. It involves the exercise and development of various skills aimed at bridging the gap between a current and the desired state. Writing is similar to critical thinking in that it requires the integration and execution of various skills, including argument, organisation, and planning, as well as a working comprehension of grammar and punctuation rules. There are three categories of writing activities - basic tasks, process issues, and outcomes - can link critical thinking to writing. So critical thinking is an activity that relates to the ability and action. While the assessment of critical thinking used Critical Thinking Test through multiple choice questions to interpretation; identification, conclusion, inconsistent, and completing; finding data, logical, and representative data; making a prediction, other answer choosing and the hypothesis of what people think.

Thus, the role of cooperative learning and critical thinking has been emphasized by many researchers (e.g. Johnson, Johnson Holubec 1994; Kabilan, 2000; Stapleton, 2002) stated that the skills in writing are not acquired but culturally transmitted. The students' writing skills do not come naturally but are cultivated through much practice and conscious effort. One of the other researcher stated that one of the methods recommended in teaching writing is the incorporation of cooperative learning. Based on the result of research from Nazari and Mahmoodi (2015) about investigating the effect of cooperative learning and critical thinking on improving EFL learner' writing in a content-based classroom. Twenty students studying English as a foreign language in an Institute at intermediate level in Khoramabad, Iran, were chosen. The result of the pretest and posttest in data analysis through statistical procedure such as paired sample t-test confirmed the superiority of the experimental groups and group writing instruction helped to improve group writing.

Other result of research about cooperative learning in English class of Chinese junior high school. Wei and Tang (2015: 397) that their finding in the research; compared with the traditional ways, the implementation of cooperative learning method can, in fact, improve students' English academic achievement. Not only can it allow students to have more opportunities to learn actively and passionately, cooperate and communicate with others but also develop students' ability to integrate what they have learnt to use in real situation during the learning procedure. At the same time, the author summarizes and analyzes the advantages and disadvantages of cooperative learning and tries best to 
give suggestions for improvement, hoping that this can give some suggestions for the implementation of cooperative learning method in English class of junior high school.

Based on the problem above that the main problem in this research is essay writing learning in semester 3 with the specific problems are; 1) missing cohesion and coherence concept, 2) the teacher is still yet in using variation of model of learning like as task-based learning and think talk write, 3) the students do not have high motivation to develop their critical thinking, 4) the students cannot understand the influence of critical thinking to writing learning, and, 5) the students have low desired to write.

The lecture problem in the learning process is in material developing and learning model. Based on the observation, the lecture used general learning model is used nowadays like as talk active and discussion. It focuses on the teacher without dominating students' needs. Thus, the learning model at the time is not appropriate for the practice learning. It is a difference with task-based learning and thinks talk write learning.

In task-based learning, as generally the teacher is facilitators, and managing the class in order to be conducive. To facilitate learning needs conducted the balancing between action and language, and decided those are real quality. According to Willis (1996:40), the TBL framework so far provides the three basic conditions for language learning, exposure, use and motivation. The task cycle offers learners a holistic experience of language in use. In a TBL framework, most of the emphasis is on learners doing things, often in pairs of the group, using language to achieve the task outcomes and guided by the teacher.

Think-talk-write model is one of the approaches to communicative learning that is developing the students' ability are: (1) reading and writing, and accepting and giving information. According to Huinker and Laughlin that is a quote by Huda (2014:218), think-talk-write is the strategy that facilitates language exercise as orally and writing. This strategy pushed the students to think, to speak, to write the topic. But Freisinger has been a quote by Babin and Harrison (1999:251) that talk and write is the effort to create students in the learning process as a natural source of speaking because they start the writing. So, it concluded that writing used talk - write process is easier for the students in expressing of ideas that have been had. Those strategies in cooperative learning are assumed can increase students' critical thinking in essay writing learning. While, the main problems of students are motivation, thinking pattern, and self-regulated learning. Think-Talk-Write is a cooperative learning strategy introduced by Huinker and Laughlin. This strategy basically built through thinking, speaking and writing. Think-Talk-Write focuses on how the students thinking clearly about a topic. By thinking, students learn to find so many ideas and information related to the topic. All of the information by individually then will be talked in a discussion of group. By talking, each student in a group will learn how to share their idea and information and compile it in a written form by writing skill.

Based on the background of problem and limitation of the problem, the research focuses on the influence of cooperative learning and critical thinking on essay writing skills. These are the detail of problem;

1) How is English essay writing skill between students that was learned by task-based learning and think talk write learning?

2) How is the interaction between cooperative learning model and critical thinking on English essay writing skill?

3) How is English essay writing skill between students that were learned by task-based learning and think talk write learning in high critical thinking?

4) How is English essay writing skill between students that was learned by task-based learning and think talk write learning in low critical thinking?

\section{Methodology of Research}

The research did in STKIP PGRI Lampung, Indonesia on March until December 2016. It is quantitative research with experiment method using treatment by level $2 \times 2$ design. It is the matrix of research planning.

The writer used multi-stage cluster random sampling to take the sample of research. The sample is the fourth semester that divided two groups. Based on the Guilford's theory, the sample will be ranked $27 \%$ for the high group and $27 \%$ for the low group. In this research, there are 22 students that divided as experiment group and control group. In high critical thinking group, the students will be divided two parts, the first 11 students were learning using task-based learning and 11 students were learning think-talk-write learning. It is the same for the low critical thinking group. 
Table 1. Treatment by Level Design

\begin{tabular}{lcc}
\hline & \multicolumn{2}{c}{ Cooperative Learning Model (A) } \\
\cline { 2 - 3 } Critical Thinking (B) & Task-based learning $(\mathrm{A} 1)$ & Think-talk-write learning $\left(\mathrm{A}_{2}\right)$ \\
\hline Tinggi $\left(\mathrm{B}_{1}\right)$ & $\mathrm{A}_{1} \mathrm{~B}_{1}$ & $\mathrm{~A}_{2} \mathrm{~B}_{1}$ \\
Rendah $\left(\mathrm{B}_{2}\right)$ & $\mathrm{A}_{1} \mathrm{~B}_{2}$ & $\mathrm{~A}_{2} \mathrm{~B}_{2}$ \\
\hline
\end{tabular}

The validity of the research used internal and external validity. There are seven criteria from Campbell and Stanley in Art, et.al., 1) history (the process of experiment research did appropriate with the schedule from the academy. It is to prevent some events that can happen and influence the experiment). 2) Maturation (time of experiment is not long. It is one semester). 3) Testing (the purpose is to know respondent's skill. In this research compare the first and the end of research result). 4) Instrumentation. 5) Morality (the writer did control to the attendance of student during the experiment). 6) Statistical regression. 7) Selection. While external validity is population and ecology. The purposes are to control the validity of research result. The researcher did not change condition the class and observation did not do clear. So, the research did like as the process of learning.

Test validity is based on the theoretic test that has been done by an expert. The result of the expert assessment shows the appropriate to use. Reliability of the instrument is used correlation technique that is product moment. The result is reliable. Based on the result $r$ account is 0.722 and $r$ table with $n=20$ in significance level $5 \%$ is 0.444 . While $r$ table with $\mathrm{n}=20$ in significance level $1 \%$ is 0.561 . so, the result is $0.722>0.561>0.444$. The conclusion that instrument of descriptive writing is reliable and it can use for the research.

\section{Result}

Based on the pretest and posttest data analysis, there are the result of statistic result in descriptive data that showed the differences of essay writing score between groups. Those are 8 differences of English essay writing score; 1) score of essay writing that has learned using task-based learning, 2) score of essay writing that has learned using think-talk-write learning, 3) score of essay writing is in high critical thinking group, 4) score of essay writing is in low critical thinking, 5) score of essay writing between students that were learned by task-based learning in high critical thinking, 6) score of essay writing between students that were learned by task-based learning in low critical thinking, 7) score of essay writing between students that were learned by think-talk-write learning in high critical thinking, and 8) score of essay writing between students that were learned by think-talk-write learning in low critical thinking. The result show in the following table;

Table 2. Statistic Desriptive Data

\begin{tabular}{|c|c|c|c|c|c|c|c|c|c|}
\hline & & PBT & PTTW & BKT & BKR & $\begin{array}{l}\text { PBT } \\
\text { BKT } \\
\end{array}$ & $\begin{array}{l}\text { PBT } \\
\text { BKR } \\
\end{array}$ & $\begin{array}{c}\text { PTTW } \\
\text { BKT } \\
\end{array}$ & $\begin{array}{c}\text { PTTW } \\
\text { BKR }\end{array}$ \\
\hline \multirow{2}{*}{$\mathbf{N}$} & Valid & 22 & 22 & 22 & 22 & 11 & 11 & 11 & 11 \\
\hline & Missing & 0 & 0 & 0 & 0 & 11 & 11 & 11 & 11 \\
\hline \multicolumn{2}{|c|}{ Mean } & 77.82 & 68.09 & 82.55 & 63.36 & 86.00 & 69.64 & 79.091 & 57.09 \\
\hline \multicolumn{2}{|c|}{ Std. Error of Mean } & 1.944 & 2.452 & 1.008 & 1.505 & 1.243 & .966 & .5793 & .847 \\
\hline \multicolumn{2}{|c|}{ Median } & 77.50 & 68.50 & 82.00 & 61.50 & 85.00 & 70.00 & 80.000 & 58.00 \\
\hline \multicolumn{2}{|c|}{ Mode } & 72 & $60^{\mathrm{a}}$ & 77 & $60^{\mathrm{a}}$ & $82^{\mathrm{a}}$ & 72 & 77.0 & 60 \\
\hline \multicolumn{2}{|c|}{ Std. Deviation } & 9.116 & 11.501 & 4.728 & 7.061 & 4.123 & 3.202 & 1.9212 & 2.809 \\
\hline \multicolumn{2}{|c|}{ Variance } & 83.108 & 132.277 & 22.355 & 49.861 & 17.000 & 10.255 & 3.691 & 7.891 \\
\hline \multicolumn{2}{|c|}{ Range } & 30 & 29 & 16 & 20 & 11 & 10 & 5.0 & 7 \\
\hline \multicolumn{2}{|c|}{ Minimum } & 63 & 53 & 77 & 53 & 82 & 63 & 77.0 & 53 \\
\hline \multicolumn{2}{|c|}{ Maximum } & 93 & 82 & 93 & 73 & 93 & 73 & 82.0 & 60 \\
\hline \multicolumn{2}{|c|}{ Sum } & 1712 & 1498 & 1816 & 1394 & 946 & 766 & 870.0 & 628 \\
\hline
\end{tabular}


Besides that, the data is too analysed about normality. The purposes are to know the normal distribution data. The spreading of normal data has important roles because it related with an accuracy of statistic test that used in this research. Here is the result of normality test;

Table 3. Tests of Normality

\begin{tabular}{cccc}
\hline & \multicolumn{3}{c}{ Kolmogorov-Smirnov $^{\mathrm{a}}$} \\
\cline { 2 - 4 } & Statistic & $\mathrm{df}$ & Sig. \\
\hline PBT & .232 & 11 & .100 \\
PTTW & .227 & 11 & .117 \\
BKT & .232 & 11 & .100 \\
BKR & .224 & 11 & .128 \\
PBTBKT & .232 & 11 & .100 \\
PBTBKR & .224 & 11 & .128 \\
PTTWBKT & .227 & 11 & .117 \\
PTTWBKR & .213 & 11 & .173 \\
\hline
\end{tabular}

From the above table showed that all group research data have tested using normality test of Liliefors. Those have normal distribution data. Because value of $\mathrm{L}_{\mathrm{o}}$ (account value of Liliefors test) is significance that is lower that $\mathrm{L}_{t}$ (Critics value or table value $(0.05))$ or $\operatorname{Lo}<\mathrm{Lt}(0.05=0.190)$. While homogeneity test is;

Table 4. The Result of Homogeneity Test

\begin{tabular}{cccccc}
\hline Group & $\mathbf{s i}_{\mathbf{~} \mathbf{g a b}}$ & $\mathbf{B}$ & $\mathbf{X}_{\mathbf{0}} \mathbf{}$ & $\mathbf{X}^{\mathbf{2}} \mathbf{t}$ & Conclusion \\
\hline A1B1, A2B1, & 0.097 & -40.514 & -178.64 & 7,81 & Homogenous \\
A1B2, A2B2 & & & & & \\
A1, A2 & 107.69 & 107.69 & 1,123 & 3.481 & Homogenous \\
B1, B2 & 24.929 & 58.662 & -12.28 & 3.481 & Homogenous \\
\hline
\end{tabular}

Thus, the research data continued with hypothesis test using ANOVA. Here is the result of ANOVA;

Table 5. The Result of two Ways ANOVA Test

\begin{tabular}{lllllc}
\hline \multicolumn{1}{c}{ Variant source } & \multicolumn{1}{c}{ DB } & \multicolumn{1}{c}{ JK } & \multicolumn{1}{c}{ RK $=\mathbf{J K} / \mathbf{D B}$} & $\mathbf{F h}=\mathbf{R K} / \mathbf{R D K}$ & $\mathbf{F t}$ \\
\hline between rows (b) & 1 & 4047.41 & 4047.41 & 460.46 & 4.08 \\
between column (k) & 1 & 1040.81 & 1040.81 & 118.41 & \\
interaction (bk) & 1 & 87.29 & 87.29 & 9.93 & \\
& 40 & 351.46 & 8,79 & - & - \\
\hline
\end{tabular}

\section{Discussion}

Based on the descriptive statistic data, the conclusion is the average score of English essay writing skills that had learned using task-based learning is 77.82. It is a difference with the score in another learning model. Students' score that had learned using think-talk-write (TTW) is 68.09. So, those learning model have the influence to students' ability in essay writing learning. Both of them has difference score. Task-based learning is better than think-talk-write (TTW).

Even though, there is other interpretation if comparing with another aspect relevancy, such as students' critical thinking pattern. From the statistic, descriptive data concluded that in the high critical thinking group has the average score of English essay writing skills is a difference with the group that has learned using task-based learning and 
think-talk-write (TTW). The average is 82.55 and 63.36. the conclusion that there is a high quarrel or difference of the score. It depends on the critical thinking pattern. Based on the result of two ways ANOVA test that showed in Table 5, concluded the hypotheses of the problem are;

1. The first hypotheses: $F_{h i t u n g} / F h(k)=118.41$ with $F t(0,05)(1,40)=4.08$. it is $F h(k)>F t$, so Null hypotheses (Ho) is rejected and H1 is received. So, there is the significance influence between rows. English essay writing skills in a group that had learned using task-based learning are better that the group has learnt using think-talk-write (TTW). It is understood from the average score of essay writing skills that learned using task-based is about (77.82) is higher that the group that had learnt using think-talk-write (TTW) is about (68.09).

2. The second hypotheses: ANOVA table showed that Fh (bxk) is 9.93 , and $\mathrm{Ft}(0,05(1,40)$ is 4.08 . so, Fh(k) $>$ Ft, so Null hypotheses (Ho) is rejected and $\mathrm{H} 1$ is received. Thus, there is an interaction between cooperative learning and critical thinking on English essay writing skills. then, it continued with Tukey test.

3. The third hypotheses: after, the research found that the first and the second hypotheses, it continued with English essay writing test for the group that has learnt using task-based learning is comparing with think-talk-write (TTW) for the students have high critical thinking (A1B1 comparing with A2B1), it showed that $\mathrm{Q}_{\text {account }}$ is 12.91, Q table (in significance value $5 \%$ ) is about 2,87. So, Q account $>\mathrm{Q}$ table in significance value 5\%. Thus, the students that learned English essay writing using task-based learning is better than think-talk-write (TTW) for the high critical pattern.

4. The third hypotheses: English essay writing test for the group that has learnt using task-based learning is comparing with think-talk-write (TTW) for the students have low critical thinking (A1B2 comparing with A2B2), it showed that $\mathrm{Q}_{\text {account }}$ is 14.1 , Q table (in significance value $5 \%$ ) is about 2,87. So, Q account $>$ Q table in significance value 5\%. Thus, the students that learned English essay writing using think-talk-write (TTW) is better than task-based learning for the low critical pattern.

Based on the hypothesis analysis, it concluded that task-based learning and thin-talk-write learning are able to use in essay writing learning both of in high or low critical thinking. It gives a significant data that incresed students' writing skills. of course, it will have difference treatment for each group learning. each student has theirselves characteristic thinking. But the teacher can be used other media of learning to maximize the learning. Beside that, the teacher needs more effort to apply those learning because of difference students' characteristic. Payman and Girjian (2014:201-216) has developed the effect of task-based strategies on students' writing skill among translatio students. Findings revealed that the mind mapping and class discussion groups outperformed the oral summary group. However, mind mapping group outperformed both groups. Implications for future English teaching and learning could be the use of mind mapping tasks which develops EFL learners' writing proficiency. Thus, through analyzing the passages in the classroom, the learners were able to discover the passage structures and use this knowledge in their writing process.

Other research is from Nazari, et.al that the results also showed a positive correlation between the two independent variables of Cooperative Learning and EFL learners' Critical Thinking performance. In following, the results of the analysis are discussed regarding the relationships between and among the variables of the study. We can conclude that there are high and positive inter correlations among the scores of all sessions depends on the raters' scores. It has the same result with this study. As researchers and theorists have long maintained, language and thinking skills are closely related and inseparable (Piaget, 1971; Renner, 1996; Vacca, \& Gove, 1995; Vygotsky, 1962) and also the comprehension of content area knowledge, made the learning meaningful (Krashen, 1985) and enhanced the students' academic language skills (Chamot \& O'Malley, 1986, 1987; Cummins, 1981, 1984). In this study, we understood that all of the students liked to work in a group work and complete their works by helping and using teammates' help, they said that it caused to make them be more eager and it increased their confidence.

Some researcher should the cooperative learning and critical thinking to increase writing skill. In this study is trying to increase students writing skill about essay writing. the study focuses in task-based learning and think-talk-write. The task based learning gives more chance to students in writing practice. For Indonesia students, writing in English is very difficult because it has different context in structure. While, task-based learning has new way to students in writing. The task-based strategy provides learners with interesting challenges and is clearly related to their language needs (Fatehi rad \& Mohammad Jafari, 2013). Pre-task phase provides a chance for students to predict the performance of the task. These activities have also proved interesting. By using it students' writing accuracy will improve in a number of ways specially by focusing their attention to the main task again.

In think-talk-write learning model focuses to build the thinking capacity, ability in managing of idea in a group. This 
model has facilitated the exercise of language both oral and written fluently. Because in writing learning, not only to learn about context but it provides the social action. Group discussion help some students to build their thinking, when they have to develop the paragraph. Wolpert and Gawron (2014:13), the TTW strategy, Think Talk Write is a strategy I originally learned from the California Writing Project. For secondary students, this startegy is vital. Writing us about communicating ideas that are in one's head. But the teenagers especially, brainstorming and discussion is key in homing in on the highest level (or appropriate) ideas on which to write

Thus, the study shows that, task-based learning and think-talk-write learning give a new solution in essay writing problem, especially for Indonesia's students. In the classroom, the students can create the team, group discussion, individual of learning process, increased motivation and critical thinking, and new way of practice type. The model of learning gives a positive impact to the process of teaching learning. The result showed that each group received feedback through activities in a group or partner and it gives impact to individual learning. Like as in low critical thinking, the students are able to manage their critical thinking in writing. Not only that, they have a good motivation to discuss in a group but also controlling the time to learn. There is a significant result of essay writing score. It showed in the pretest and posttest.

\section{Conclusion}

Based on the analysis and finding data in implementing of cooperative learning in essay writing learning process in semester III of English major STKIP Bandar Lampung has significance on the increasing of essay writing skills. The students are able to manage the critical pattern that is better than before they learn using this model learning. The research found some limitation, those are;

1. Critical thinking and cooperative learning have significance influence to essay writing learning.

2. The teacher has to prepare the media of learning in implementing of the cooperative learning model.

3. Management class. Managing of the class must be understood by each teacher when they used the model learning, such as think-talk-write (TTW) or another model learning because it has difference characteristic.

4. To know the students' critical thinking pattern in the research, used multiple choice of test. But the test is not one instrument to identify of critical thinking pattern. There are some types of test that can be used to classified the critical thinking. In STKIP PGRI Lampung, Indonesia has other purposes in writing learning, so the test used in the research is multiple choice.

5. Critical thinking pattern divided two categories. Those are high and low. While in a class, there is a student who is different thinking pattern. In this research is not developing through another thinking pattern.

6. The research still focuses on one language skills that are essay writing, as it knows that there are many types of writing learning.

While on the basis of the finding of his research, the following implications of the result of research are recommended. This study couls be a startibf point in investigation of the role of discussion in think-talk-write model learning and task-based learning in writing accuracy. Many language teachers in EFL contexts treat writing skill in a traditional way ignoring the discussion. They usually overlook the fact that many language learners have difficulty in this skill. In language

classrooms, it is recommended that language teachers also familiarize their language learners with the importance of utilizing discussion. Here some recommended implication that are able to be used by teacher in essay writing learning;

1. In learning and teaching process at the class, the result of research gave other ways to create good learning and developing motivation for the students in writing learning.

2. The research gave an implication on developing of class managing or class management. Because the learning model applied in this research related to teacher's creativity to manage the class when the learning process happened.

3. For the lecture, task-based learning and think-talk-write (TTW) learning can be used the guide to developing cooperative learning model in the class. The teacher is not only used these model for another writing major. The effectiveness of research result increased the writing skills' students in STKIP PGRI Lampung. But, the teacher is able to create the learning that is more creative in order that cooperative learning applied in other major or it combined with another learning model or strategic of learning. 
4. For the College, the result of research is able to use as a part of increasing process of language skills' students in English Department. Because the progressing of program study depends on the students' skills.

5. For the foreign language learner, they are able to manage their critical and creative thinking in order that the learning is easier. Because writing learning needs more imagination. The result of research can help the foreign language students manage their writing learning better.

The result of research is not limited to the essay writing learning. The next research is able to develop for another English skill. The researcher is able to find otter aspect both of from students aspect or teacher and facility aspect. Increasing English essay writing is not only needed the critical thinking, but also another aspect like as motivation, vocabulary mastery, material or another component. But the result of research has more impact on essay writing learning, especially for the foreign language learner.

\section{References}

Babin, Edith \& Kimberly Harrison. (1999). Contemporary Composition Studies A Guide to Theories and terms. New York: Greenwood Press

Blanchard, Karen \& Christine Root. (2004). Ready to Write More: From Paragraph to Essay (2nd Edition). New York: Longman.

Brown, Douglas. (2003). Language Assessment Principles and Classroom Practices. San Francisco, California: Longman.

Browne, M. Neil \& Stuart M. Keeley. (2007). Asking the Right Question, A Guide to Critical Thinking. New Jersey: Pearson.

Chamot, A.U., \& O'Malley, J. M. (1994). The CALLA Handbook: implementing the Cognitive Academic Language Learning Approach. Reading, MA: Addison-Wesley.

Cummins, J. (1981). The role of primary language development in promoting educational success for languageminority students. In C. F. Leyba (Ed.), Schooling and language minority students: A theoretical framework. Los Angeles, California: Evaluation, Dissemination, and Assessment Center.

Cummins, J. (1984). Bilingual and special education. San Diego, California: College Hill.

Dunn, Dana S., Jane S. Halonen, \& Radolph A. Smith. (2008). Teaching Critical Thinking in Psychology A Handbook of best Practices. Singapore: Wiley-Blackwell. https://doi.org/10.1002/9781444305173

Fatehi rad, N., \& Mohammad Jafari, A. (2013). Teaching English and task-based method. International Journal of English language and Literature Studies, 2(2), 87-94.

Fellag, Linda Robinson. (2004). Writing Ahead: Skills for Academic Success. New York: Longman.

Folse, Keith S. April Muchmore-Vokoun, \& Elena Vestri Solomon. (2014). Great Writing 4; Great Essays (4th Edition). New York: Cengage Learning.

Krashen, S.D. (1985). The Input Hypothesis: Issues and Implications. New York: Longman.

Murray, Neil. (2012). Writing Essays in English Language and Linguistics: Principles, Tips and Strategies for Undergraduates. New York: Cambridge University Press. https://doi.org/10.1017/CBO9781139035347

Nazari, Leila \& Keivan Mahmoodi. (2015). Using Coopertaive Learning to Integrate Critical Thinking in Content based Writing Progress. International Journal of Educationa Investigations, 2(4), 136-147.

Payman, Shahram \& Bahman Gorjian. (2014). Effcet of Task Based strategies on Studens' Writing Skill Aming ranslation Students. European Journal of Business and Social Sciences, 3(3).

Piaget, J. (1971). Genetic epistemology. (E. Duckworth, Trans.) New York: W. W. Norton \& Company.

Renner, C. E. (1996, February- March). Enrich learners' language production through content-based instruction. Paper presented at a National Conference on Lingua e Nuova Didattica, Modena, Italy. (ERIC Document Reproduction Service No. ED 411 694).

Richards, Jack C., \& Willy A. Renandya. (2003). Methodology in Language Teaching: An Anthology of Current Practice. Cambridge: Cambridge University Press.

Scarry, Sandra \& John Scarry. (2011). The Writer's Workplace with Reading: Building College Writing Skills. 
Seventh Edition, New York: Wadsworth Cengage Learning.

Vacca, J. L., Vacca, R., \& Gove, M. K. (1995). Reading and learning to read. New York: Harper Collins College Publisher.

Vygotsky, L. (1962). Thought and language. Cambridge, Massachusetts: The MIT Press. https://doi.org/10.1037/11193-000

Wei, Ping \& Yu Tang. (2015). Cooperative Learning in English Class of Chinese Junior High School. Creative Education, 6, 397-404. http://dx.doi.org/10.4236/ce.2015.63039

Willis, Jane. (1996). A Framework for Task-Based Learning. Italy: Addison Wesley Longman.

Wolpert, Heather - Gawron. (2014). Writing Behind Every Door Teaching Common Core Writing in the Content Areas. New York and London: Routledge. 